\title{
PREPARATION AND EVALUATION OF SIMVASTATIN TRANSDERMAL FILM
}

\author{
HARITHA V. ANOD, N. VISHAL GUPTA, D. V. GOWDA*, MANOHAR M.
}

Department of Pharmaceutics, JSS College of Pharmacy, Sri Shivarathreeshwara Nagara, Mysuru, JSS Academy of Higher Education and Research, JSS Medical Institutions Campus, Sri Shivarathreeshwara Nagara, Mysuru 570015, Karnataka, India

Email: dvgowda@jssuni.edu.in

Received: 11 Apr 2018, Revised and Accepted: 11 Aug 2018

\section{ABSTRACT}

Objective: The objective of the study was to prepare simvastatin transdermal films for the treatment of atherosclerosis and to evaluate the effect of concentration of polymer on penetration enhancement.

Methods: Solvent evaporation technique was employed for the preparation of films and the prepared films were evaluated for various physicochemical properties of films such as tensile strength, thickness, surface $\mathrm{pH}$, swellability, drug content, moisture content and folding endurance. In vitro drug, release study and release kinetics were also studied.

Results: Tensile strength ranged from $3.56 \pm 0.343$ to $4.56 \pm 0.12\left(\mathrm{~N} / \mathrm{mm}^{2}\right)$. The films were of uniform weight. Thickness varied from $0.2 \pm 0.3 \mathrm{~mm}$ to $0.2 \pm 0.8 \mathrm{~mm}$. Surface $\mathrm{pH}$ ranged from $6.6 \pm 0.14$ to $6.9 \pm 0.16$. Percentage swellability ranged from $12.1 \pm 0.36$ to $16.3 \pm 0.22$. Percentage drug content ranged from $88.4 \pm 0.7 \%$ to $90.5 \pm 0.6 \%$ in all the formulation. Percentage moisture content ranged from 0.864 to $1.03 \%$. Moisture uptake was from $2.6 \pm 0.24$ to $2.9 \pm 0.072$. The folding endurance test gave satisfactory results and F3 formulation showed maximum drug release.

Conclusion: From the study, it was concluded that out of various formulations, the F3 formulation was found to be the optimum formulation with $88 \%$ drug release at the fourteenth hour.

Keywords: Simvastatin, Transdermal film, Solvent evaporation, Penetration enhancer, Swellability

(C) 2018 The Authors. Published by Innovare Academic Sciences Pvt Ltd. This is an open access article under the CC BY license (http://creativecommons.org/licenses/by/4.0/) DOI: http://dx.doi.org/10.22159/ijap.2018v10i5.26657

\section{INTRODUCTION}

The transdermal film is the most innovative research area in drug delivery, and it is aimed to provide a continuous supply of medication through the skin into systemic circulation. It has several advantages like maintaining constant drug level in blood, fewer side effects and improved bioavailability and patient compliance [1] being an alternative for the oral route it prevents the gastrointestinal $\mathrm{pH}$ and enzymatic deactivation of the drug along with minimizing the steps involved in the metabolising pathway [2]. Simvastatin is an HMG-CoA reductase inhibitor and acts as an antihyper-lipidemic drug and is a structural analogue of HMG-CoA [3]. The mechanism of action of HMG-CoA reductase is by usually 70 $75 \%$ LDL removing the process of endocytosis. Cholesterol esters from LDL molecules are hydrolyzed to free cholesterol in the liver. By denovo synthesis liver introduces cholesterol and this pathway involves mevalonic acid formation by the enzyme HMG-COA reductase [4]. Statins aim at inhibiting this rate-limiting enzyme and provide the therapeutic effect. Cholesterol synthesis is decreased which leads to increased synthesis of high-affinity LDL receptors which results in increased clearance (uptake) of cholesterol-rich plasma LDL with subsequent reduction in plasma LDL cholesterol by this mechanism. Statins can lower LDL level by $30-50 \%$ in maximum doses [5]. It is lipophilic in nature, and due to extensive first-pass metabolism, the plasma half-life of simvastatin is $2 \mathrm{~h}$ with an oral bioavailability of $5 \%$ [6]. To overcome this issue, various new techniques employed are transdermal, rectal, buccal and parenteral routes of administration [7]. Simvastatin is an ideal candidate for the preparation of transdermal films as it has low molecular weight $(418.56 \mathrm{~g} / \mathrm{mol})$, high lipid solubility, low melting point $\left(129^{\circ} \mathrm{C}\right)$, effective in low plasma concentration as well as a high degree of first-pass metabolism [8]. Solvent evaporation method was used for the preparation of films which involves solubilisation of the drug in a volatile solvent that is later evaporated. The thermal breakdown of drugs can be stopped since organic solvent evaporation occurs at low temperature [9].

\section{MATERIALS AND METHODS}

Simvastatin was procured from Micro labs, Bangalore, ethyl cellulose and methanol were bought from Loba Chemie, Mumbai. PEG 4000 and chloroform was procured from Merck specialties pvt ltd, Banglore. PVA was procured from Hi media laboratories pvt ltd, Mumbai [10].

Table 1: Composition of transdermal film

\begin{tabular}{|c|c|c|c|c|}
\hline \multirow[t]{2}{*}{ S. No. } & \multirow[t]{2}{*}{ Ingredients } & \multicolumn{3}{|c|}{ Formula (\%w/v) } \\
\hline & & F1 & F2 & F3 \\
\hline 1 & Simvastatin & 30 & 30 & 30 \\
\hline 2 & PVA & $12 \%$ & $12 \%$ & $12 \%$ \\
\hline 3 & Ethyl cellulose & $2 \%$ & $2 \%$ & $2 \%$ \\
\hline 4 & PEG 4000 & $12 \%$ & $15 \%$ & $15.5 \%$ \\
\hline 5 & Methanol & 2.5 & 2.5 & 2.5 \\
\hline 6 & Chloroform & 2.5 & 2.5 & 2.5 \\
\hline
\end{tabular}

\section{Preparation of transdermal film}

Solvent evaporation technique was used for the preparation of films using petri dish by adding a 12\% (w/v) PVA solution and drying for $6 \mathrm{~h}$ at $60{ }^{\circ} \mathrm{C}$. The backing membrane was produced. The reservoir of the drug was then made by adding ethyl cellulose in a mixture of chloroform, methanolin (1:1) ratio. PEG 4000 was employed as a plasticizer.

Later, simvastatin was added and stirred using a magnetic stirrer for 20 min. The homogenous preparation was cast on a backing 
membrane which contains PVA and set aside in a desiccator at room temperature for $1 \mathrm{~d}$ [11].

\section{Physicochemical characterization}

The prepared transdermal films were evaluated for physicochemical parameters.

\section{Physical appearance}

The physical appearance of transdermal films like thickness, colour, clarity, flexibility, smoothness, weight and appearance were visually inspected as per the standard procedure [12].

\section{Thickness}

The transdermal film's thickness was found out by the use of screw gauge (dial thickness gauge 7301, Mitutoyo Corporation, kanagawa, Japan) at various part of the film and readings were noted [13].

\section{Weight variation}

Different films were weighed individually by the use of digital balance (shimadzu, Japan) and variation in weight was found out and then the average weight was calculated [14].

\section{Folding endurance}

Strips were evenly cut and were evaluated by folding the film many times on the same spot till it broke. The folding endurance value was calculated by noting down the number of times it can be folded at the same spot without being broken/cracked [15]

\section{Percentage of moisture content}

Films which were prepared were separately weighed and were kept for drying in a desiccator which contains activated silica gel. It was kept for $24 \mathrm{~h}$. The percentage of moisture content was then calculated by using the below equation [16].

$$
\% \text { Moisture content }=\frac{\text { Initial weight }- \text { Final weight } \times 100}{\text { Final weight }}
$$

\section{Moisture uptake studies}

The films were weighed after $24 \mathrm{~h}$ of placing it in a desiccator containing silica gel and then transferred to another desiccator having saturated $\mathrm{KCl}$ solution of $85 \%$ relative humidity ( $\mathrm{RH})$ and allowed to attain equilibrium. Later the films were taken out and rereweighed. Moisture uptake was further determined by using the below equation.

In a desiccator containing silica gel, the films were kept for $24 \mathrm{~h}$ and then weighed and moved to another desiccator having saturated $\mathrm{KCl}$ solution of $85 \%$ RH. After attaining equilibrium, the films were taken out and weighed. By using the below formula, the moisture uptake capacity was calculated [17].

Percentage moisture uptake $=\frac{\text { Final weight }- \text { Initial weight } \times 100}{\text { Initial weight }}$

\section{Drug content}

Transdermal films were cut into pieces of a specified area $\left(1 \mathrm{~cm}^{2)}\right.$ and taken in a volumetric flask. Phosphate buffer having pH7.4 was added and shaken and kept for $24 \mathrm{~h}$. The drug in solution was determined using UV spectrophotometer (shimadzu UV 1800). Absorbance was measured at $238 \mathrm{~nm}$, and values were recorded [18].

\section{Swellability}

The weighed films were kept in a petri dish consisting of $50 \mathrm{ml}$ of phosphate buffer of $\mathrm{pH}$ 7.4and the weight was noted down for every $10 \mathrm{~min}$ interval [19]. The degree of swelling was found out using the below equation,

$$
\mathrm{S} \%=\frac{\mathrm{X}_{\mathrm{t}}-\mathrm{X}_{\mathrm{o}} \times 100}{\mathrm{Xo}}
$$

$\mathrm{X}_{\mathrm{t}}$-weight of film at time $\mathrm{t}$

$\mathrm{X}_{0}$-weight of film at time zero

S\%-percentage swelling

\section{Surface pH}

The transdermal films were kept for swelling in $0.5 \mathrm{ml}$ of double distilled water for $1 \mathrm{~h}$ in a glass tube. Combined glass electrode was then brought near the film surface and allowed to equilibrate for 1 min. The surface $\mathrm{pH}$ was then measured by using a digital $\mathrm{pH}$ meter (elico LL120type 003), and the results were noted [20].

\section{Flatness study}

This test was carried out to ensure the flat surface and nonshrinkability of the prepared transdermal films on the progression of time. Each film strip was selected and cut from different portions, the non-uniformity in flatness was determined by means of measuring the variation in length of each strip for $\%$ constriction. $100 \%$ flatness was ensured if constriction was equivalent to $0 \%$ [21].

Percentage constriction was obtained using the formula

$$
\frac{\mathrm{l}_{1-} \mathrm{l}_{2} \times 100}{\mathrm{l}_{1}}
$$

$l_{1}$ is the initial length of each strip

$l_{2}$ is the final length of each strip

\section{Tensile strength}

It was measured using the method of modified analytical two pan balance. A film of $6 \mathrm{~cm}^{2}$ wide was fixed between two clamps on one side; weights were added to the pan on another side till the film breaks. The weight required to break the film was taken as a measure of the tensile strength of the patch [22].

\section{Stability study}

Stability studies were conducted based on guidelines of ICH by keeping the films at $40 \pm 0.5{ }^{\circ} \mathrm{C}$ and $75 \pm 5 \% \mathrm{RH}$ for 6 mo. The samples were taken during $0,15^{\text {th }}, 30^{\text {th }}, 60^{\text {th }}, 90^{\text {th }}$ and $180 \mathrm{~d}$ intervals and they were analysed [23].

\section{RESULTS AND DISCUSSION}

Table 2: Evaluation of transdermal patches

\begin{tabular}{llll}
\hline S. No. & Properties & F1 mean \pm SD & F2 mean \pm SD \\
\hline 1 & Thickness(mm) & $0.2 \pm 0.3$ & $0.2 \pm 0.6$ \\
2 & Folding endurance & $297.0 \pm 2.63$ & $298.2 \pm 2.01$ \\
3 & Percentage moisture content & 0.91 & 1.03 \\
4 & Tensile strength N/mm $\mathrm{mm}^{2}$ & $3.56 \pm 0.343$ & $29.2 \pm 0.8$ \\
5 & Moisture uptake & $2.6 \pm 0.24$ & $0.56 \pm 0.12$ \\
6 & Percentage Swellability & $12.1 \pm 0.36$ & $2.7 \pm 0.32$ \\
7 & Flatness & 100 & $15.3 \pm 0.41$ \\
8 & Surface pH & $6.6 \pm 0.14$ & 100 \\
9 & Drug content & $97.3 \pm 0.3$ & $6.7 \pm 0.12$ \\
\hline
\end{tabular}

mean \pm SD, $n=3$ 


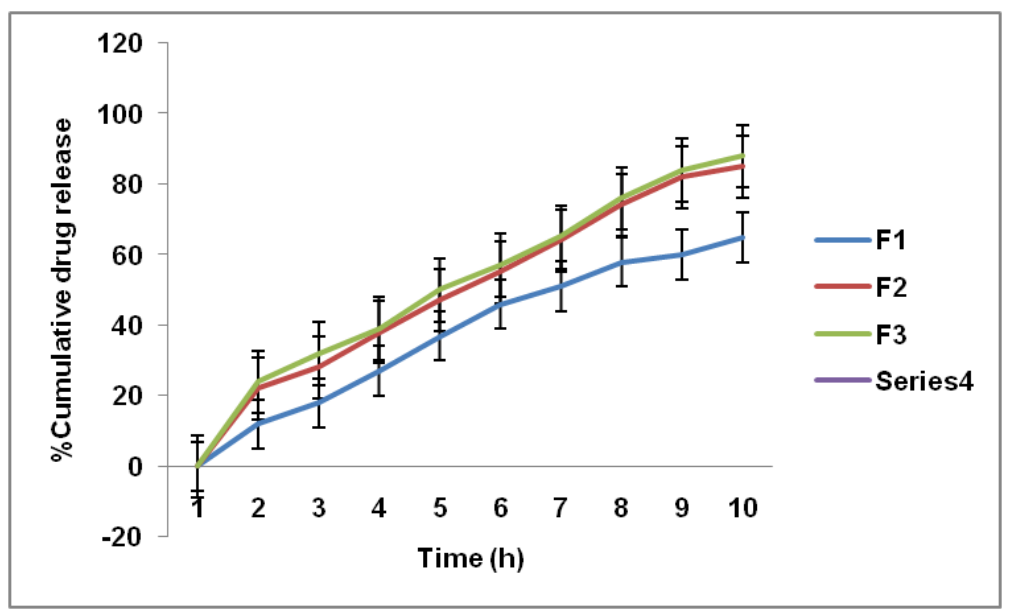

Fig. 1: Cumulative \% drug release of F1, F2, and F3

\section{Kinetic modelling of drug release}

The pattern of drug release from formulations was analysed using BCP software. The release profile of the formulations was fitted into release kinetic models like first order, zero order, and higuchi. This is shown in table 4. F1 and F3 formulation showed first order release with correlation coefficient $\left(\mathrm{R}^{2}\right)$ value 0.9770 and 0.9919 respectively. F2 formulation showed zero order release. F3 formulation was found to show maximum drug release. According to S. Parmaret al. the percentage drug release was found to be $80 \%$ when a novel approach such as spherical agglomerate was made [24]. And according to A. M. Pethe et al,, a mucoadhesive buccal tablet of simvastatin showed $65.96 \%$ drug release [25]. The transdermal films in the present study showed more than $88 \%$ of drug release which states that transdermal delivery of simvastatin has a higher percentage of drug release when compared to others.

Table 4: Kinetic modelling of drug release

\begin{tabular}{llll}
\hline Formulation code & Zero-order & First order \\
\hline F1 & 0.9317 & 0.9770 & 0.9200 \\
F2 & 6.608 & 0.9945 & 0.9170 \\
F3 & 0.9251 & 0.9919 & 0.9197 \\
\hline
\end{tabular}

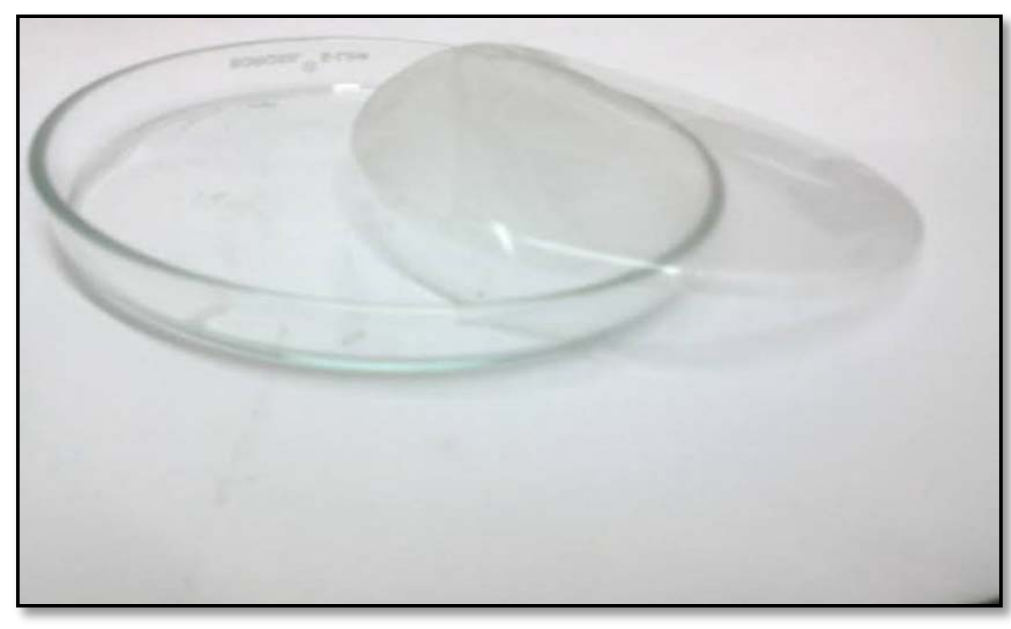

Fig. 2: Transdermal film (F3 formulation)

Prepared transdermal films are of F3 formulation. It showed good physicochemical characteristics with good flexibility and maximum drug release. It is used in minimizing dose and increased patient compliance. According to Bhawana et al. polyethylene glycol used is best suited as a plasticizer as compared to others such as glycerine since it shows good physicochemical properties like thickness, moisture uptake, moisture absorption etc and drug release profile [26]. In the studies conducted by Shailesh et al., the transdermal films which contained polyethylene glycol were having optimum flexibility and were not brittle [27]. According to Prathiket al. formulation with ethyl cellulose gave good folding endurance [28] and also according to Gajanan et al. with the increase of ethyl cellulose in the formulation, the moisture uptake, as well as the moisture content, was increased [29].

The physicochemical properties of films are depicted in the table 2 . Tensile strength ranged from $3.56 \pm 0.343$ to $4.56 \pm 0.12\left(\mathrm{~N} / \mathrm{mm}^{2}\right)$. The films were of uniform weight. Thickness varied from $0.2 \pm 0.3$ to $0.2 \pm 0.8 \mathrm{~mm}$. Surface $\mathrm{pH}$ ranged from $6.6 \pm 0.14$ to $6.9 \pm 0.16$. Percentage swell ability ranged from $12.1 \pm 0.36$ to $16.3 \pm 0.22$. Percentage drug content ranged from $88.4 \pm 0.7 \%$ to $90.5 \pm 0.6 \%$ in all the formulation. Percentage moisture content ranged from 0.864 to 
$1.03 \%$. Moisture uptake ranged from $2.6 \pm 0.24$ to $2.9 \pm 0.072$. The folding endurance test gave satisfactory results. F3 formulation showed maximum drug release. It was found that as the concentration of PEG increased the release of the drug was decreased. Hence the incorporation of polyethylene glycol and ethyl cellulose in the formulation was responsible for exhibiting good physiochemical properties.

\section{CONCLUSION}

Transdermal films were prepared, and all the formulations showed good physicochemical properties and the type of polymer used and its concentration was found to affect the drug release. The study concluded that as the penetration enhancer's concentration increases the drug permeation was also increased. Stability studies of the drug formulations proved that the drug was stable in the optimized transdermal film formulation. It can be concluded that the films prepared has the potential for simvastatin drug delivery with improved permeation.

\section{ACKNOWLEDGMENT}

The authors acknowledge JSS College of Pharmacy for providing the support and encouragement.

\section{AUTHORS CONTRIBUTIONS}

All the authors have contributed equally.

\section{CONFLICT OF INTERESTS}

Declared none

\section{REFERENCES}

1. Rajesh N, Siddaramaiah D Gowda, Somashekar C. Formulation and evaluation of biopolymers based transdermal drug delivery. Int J Pharm Pharm Sci 2010;2:142-7.

2. Hardainiyan S, Kumar K, Nandy BC, Saxena R. Design, formulation and in vitro drug release from transdermal patches containing imipramine hydrochloride as a model drug. Int J Pharm Pharm Sci 2017;9:220-5.

3. Manjunath PN, Satish CS, Vasanti S, Preetham AC, Naidu Ras. Formulation and evaluation of simvastatin gastro retentive drug delivery system. Int J Appl Pharm 2017;9:55-60.

4. Surender V, Vipul M. Formulation, evaluation and optimization of transdermal patches of losartan potassium. World J Pharm Sci 2016;4:277-84.

5. Evane B, Singh S, Mishra A, Pathak AK. Formulation and evaluation of transdermal drug delivery system of simvastatin. J Pharm Res 2012;5:810-3.

6. Shelke S, Kairnar A, Vivek R, Yogesh K, Ashish J. Review on antihyperlipidemic lipophilic drugs and their novel formulation approaches. Int J Pharm Pharm Sci 2017;9:1-8.

7. Bhaskar V, Prakash RND. Development, characterisation, and evaluation of simvastatin solid lipid nanoparticles loaded the transdermal patch. J Chem Pharm Sci 2016;9:702-8.

8. Naseera K, Sajeeth CI, Santhi K. Formulation, optimization and evaluation of matrix type of transdermal system of simvastatin using permeation enhancers. Int J Curr Pharm Res 2012;4:7987.
9. Kurmi R, Mishra DK, Jain DK. Solid dispersion: a novel means of solubility enhancement. J Crit Rev 2016;3:1-8.

10. Zidan AS, Hosny KM, Ahmed OA, Fahmy UA. Assessment of simvastatin niosomes for pediatric transdermal drug delivery. Drug Delivery 2016;23:1536-49.

11. Patel RP, Patel G, Baria A. Formulation and evaluation of transdermal patch of aceclofenac. Int J Drug Delivery 2009;1:41-51.

12. Jadhav RT, Kasture PV, Gattani SG, Surana SJ. Formulation and evaluation of transdermal films of diclofenac sodium. Int J Chem Tech Res 2010;2:354-60.

13. Can AS, Erdal MS, Gungor S, Ozsoy Y. Optimization and characterization of chitosan films for transdermal delivery of ondansetron. Molecules 2013;18:5455-71.

14. Kumar J, Lakshmana P, Gopal P. TDDS: an overview. Int J Pharm Sci Rev Res 2010;3:49-54.

15. Nayak B, Ellaiah P, Pattanayak D, Das S. Formulation design preparation and in vitro characterization of nebivolol transdermal patches. Asian J Pharm 2011;5:175-82.

16. Kadam AS, Ratnaparkhi MP, Chaudhary SP. Transdermal drug delivery: an overview. Int J Res Dev Pharm Life Sci 2014;3:1042-53.

17. Tanwar H, Sachdeva R. Transdermal drug delivery system: a review. Int J Pharm Pharm Sci 2016;7:2274-90.

18. Sudam KR, Suresh BR. A comprehensive review on: transdermal drug delivery systems. Int J Biomed Adv Res 2016;7:147-59.

19. Mali AD, R Bathe, Manoj KP. An updated review on transdermal drug delivery systems. Int J Adv Sci Res 2015;1:244-54.

20. Humama F, Shalini S. Development and evaluation of the transdermal therapeutic system of an antihypertensive drug. Int Res J Pharm 2015;6:213-8.

21. Bharkatiya M, Nema RK, Bhatnagar M. Development and characterization of transdermal patches of metoprolol tartrate. Asian J Pharm Clin Res 2010;3:130-4.

22. Ravi G, Vishal Gupta N. Development and evaluation of transdermal film containing solid lipid nanoparticles of rivastigmine tartrate. Int J Appl Pharm 2017;9:85-90.

23. Kusumdevi V, Asha AN, Agadi SS, Mathew D. Optimization of transdermal delivery of selected antihyperlipidaemic agentsstatin. J Drug Delivery Res 2013;2:1-23.

24. S Parmar, Rakesh M, SV Shirolkar. Spherical agglomeration a novel approach for solubility and dissolution enhancement of simvastatin. Asian J Pharm Clin Res 2016;9:65-72.

25. Pethe AM, Salunkhe SP, Premchandani TA. Formulation and evaluation of mucoadhesive buccal tablet of simvastatin. Int J Pharm Bio Sci 2014;5:268-78.

26. Bhawana S, Rupa M. Comparative evaluation of selected polymers and plasticizer on transdermal drug delivery system. Int J Appl Pharm 2018;10:67-73.

27. Prajapati ST, Patel CG, Patel CN. Formulation and evaluation of transdermal patch of repaglinide. ISRN Pharm 2011:1-9. Doi:10.5402/2011/651909

28. PS Das, P Saha. Design and characterisation of transdermal patches of phenforminhydrochloride. Int I Curr Pharm Res 2017;9:90-3.

29. Darwhekar G, Jain DK, Patidar VK. Formulation and evaluation of transdermal drug delivery system of clopidogrel bisulfate. Asian J Pharm Life Sci 2011;1:269-78. 